\title{
Prostaglandins $E_{2}$ and $F_{2 \alpha}$ affect glycogen synthase and phosphorylase in isolated hepatocytes
}

\author{
Anna M. GÓMEZ-FOIX, Joan E. RODRIGUEZ-GIL, Joan J. GUINOVART* and Fàtima BOSCH \\ Department of Biochemistry, Autonomous University of Barcelona, School of Veterinary Medicine, \\ 08193-Bellaterra (Barcelona), Spain
}

\begin{abstract}
Prostaglandin $\mathrm{E}_{2}\left(\mathrm{PGE}_{2}\right)$ and prostaglandin $\mathrm{F}_{2 \alpha}\left(\mathrm{PGF}_{2 \alpha}\right)$ inactivated glycogen synthase and activated glycogen phosphorylase in rat hepatocytes in a dose- and time-dependent manner. These effects were dependent on the presence of $\mathrm{Ca}^{2+}$ in the incubation medium. When glycogen synthase was immunoprecipitated from cells incubated with $\left[{ }^{32} \mathrm{P}\right] \mathrm{P}_{\mathrm{i}}$ and then treated with $\mathrm{PGE}_{2}$ or $\mathrm{PGF}_{2 \alpha}$, there was increased phosphorylation of the $88 \mathrm{kDa}$ subunit of the enzyme. This phosphorylation affected two $\mathrm{CNBr}$ fragments of the glycogen synthase, CB-1 and CB-2, the same fragments that are phosphorylated by different glycogenolytic hormones. No phosphorylation of glycogen synthase by prostaglandins was observed in the absence of $\mathrm{Ca}^{2+}$. Thus the effect of $\mathrm{PGE}_{2}$ and $\mathrm{PGF}_{2 \alpha}$ on these glycogen-metabolizing enzymes supports a role for regulation by prostaglandins of glucose metabolism in parenchymal liver cells.
\end{abstract}

\section{INTRODUCTION}

Glycogen synthase and glycogen phosphorylase are the key enzymes in the regulation of glycogen metabolism. The activities of both enzymes are controlled through phosphorylation-dephosphorylation reactions. Phosphorylation activates phosphorylase and inactivates glycogen synthase. Glycogen synthase is phosphorylated by the action of glycogenolytic hormones (acting through cyclic AMP- or $\mathrm{Ca}^{2+}$-mediated mechanisms) at multiple sites contained in two $\mathrm{CNBr}$ fragments. In the rat liver these phosphopeptides show molecular masses of $14 \mathrm{kDa}$ (CB-1) and $28 \mathrm{kDa}$ (CB-2) [1,2].

It has been shown recently that prostaglandins are able to stimulate glycogenolysis in perfused rat liver [3-5] or in parenchymal liver cells [5-7]. Moreover, it has been proposed that prostaglandins may be the mediators of the effects of several agents, such as $4 \beta$-phorbol $12 \beta$-myristate $13 \alpha$-acetate and platelet-activating factor $[5,8-10]$ on hepatic glucose metabolism through an intercellular communication mechanism. These two agents are able to stimulate the secretion of prostaglandins from non-parenchymal cells [5,11,12], and in this way they may modulate parenchymal-cell metabolism.

The aim of the present study was to examine the ability of prostaglandins to regulate the glycogen-metabolizing enzymes in isolated hepatocytes. We provide evidence that prostaglandins promote the inactivation and phosphorylation of glycogen synthase and the activation of phosphorylase in a $\mathrm{Ca}^{2+}$-dependent manner. Thus our results support the idea that prostaglandins may exert a control on liver glycogen metabolism.

\section{MATERIALS AND METHODS}

\section{Isolation and incubation of the cells}

Suspensions of isolated parenchymal liver cells were prepared from starved $(24 \mathrm{~h})$ male Wistar rats as described previously [13]. Cells were resuspended in a
Krebs bicarbonate buffer ( $\mathrm{pH} 7.4)$ free of glucose (containing $118.5 \mathrm{~mm}-\mathrm{NaCl}, 4.8 \mathrm{~mm}-\mathrm{KCl}, 2.5 \mathrm{~mm}-\mathrm{CaCl}_{2}$, $25 \mathrm{~mm}-\mathrm{NaHCO}_{3}, 1.2 \mathrm{mM}^{-\mathrm{KH}_{2}} \mathrm{PO}_{4}$ and $1.2 \mathrm{~mm}-\mathrm{MgSO}_{4}$ ), which was equilibrated with $\mathrm{O}_{2} / \mathrm{CO}_{2}(19: 1)$. When stated, $\mathrm{Ca}^{2+}$ was omitted from this medium and 1 mM-EGTA was added. Samples $\left(4 \times 10^{6}-5 \times 10^{6}\right.$ cells $\left./ \mathrm{ml}\right)$ were preincubated for $20 \mathrm{~min}$, and then prostaglandins were added at the indicated concentrations. Stock solutions of prostaglandins were made in dimethyl sulphoxide. At the end of the incubation, cells were centrifuged and cell pellets homogenized as described previously [14].

\section{Isolation of ${ }^{32} \mathbf{P}$-labelled glycogen synthase}

Glycogen synthase was isotopically labelled by preincubation of hepatocytes for $45 \mathrm{~min}$ with $\left[{ }^{32} \mathrm{P}\right] \mathrm{P}_{\mathrm{i}}$ $(0.1 \mathrm{mCi} / \mathrm{ml})$ in a low-phosphate $(0.1 \mathrm{mM})$ version of the above Krebs bicarbonate buffer ( $\mathrm{pH}$ 7.4). Cytosolic fractions were prepared from the $10000 \mathrm{~g}(15 \mathrm{~min})$ supernatants by ultracentrifugation at $100000 \mathrm{~g}$ for $60 \mathrm{~min}$ at $4{ }^{\circ} \mathrm{C} .{ }^{32} \mathrm{P}$-labelled glycogen synthase was isolated by immunoprecipitation [15] by using specific antibodies. For $\mathrm{CNBr}$ cleavage, immunopellets were treated as described in ref. [14].

The analysis of glycogen synthase subunit or $\mathrm{CNBr}$ phosphopeptides was carried out by electrophoresis in polyacrylamide gels in the presence of SDS, with 7\%acrylamide or 6-20\%-gradient-acrylamide slab gels as described in ref. [16]. Samples for SDS/polyacrylamidegel electrophoresis were evaporated to dryness and resuspended in $30 \mu \mathrm{l}$ of sample buffer, containing $40 \mathrm{~mm}$ Tris (pH 6.5), $5 \%$ (w/v) SDS, $0.6 \mathrm{~m}$-2-mercaptoethanol, $20 \%(w / v)$ sucrose and $0.0125 \%$ (w/v) Bromophenol Blue as a marker. Autoradiograms were obtained, and the amount of radioactivity was quantified by scanning the developed films at $546 \mathrm{~nm}$.

\section{Enzyme assays}

Glycogen synthase activity ratio was measured by using the low-glucose 6-phosphate/high-glucose 6-

Abbreviations used: $\mathrm{PGE}_{2}, \mathrm{PGF}_{2 \alpha}$, prostaglandin $\mathrm{E}_{2}$ and $\mathrm{F}_{2 \alpha}$

* To whom reprint requests should be addressed. 
phosphate method as described previously [17]. Glycogen phosphorylase activity was measured as in ref. [18]. Protein was determined by the biuret method [19] as in ref. [20].

\section{Materials}

$\left[{ }^{32} \mathrm{P}\right] \mathrm{P}_{\mathrm{i}}$ was obtained from Amersham International. Prostaglandins were from Sigma. All other reagents were analytical grade.

\section{RESULTS}

Effects of PGE $_{2}$ and $\mathrm{PGF}_{2 \alpha}$ on the activation state of glycogen synthase and glycogen phosphorylase activity

The incubation of isolated hepatocytes with $25 \mu \mathrm{M}$ $\mathrm{PGE}_{2}$ or $20 \mu \mathrm{M}-\mathrm{PGF}_{2 \alpha}$ for different times caused an activation of glycogen phosphorylase and an inactivation

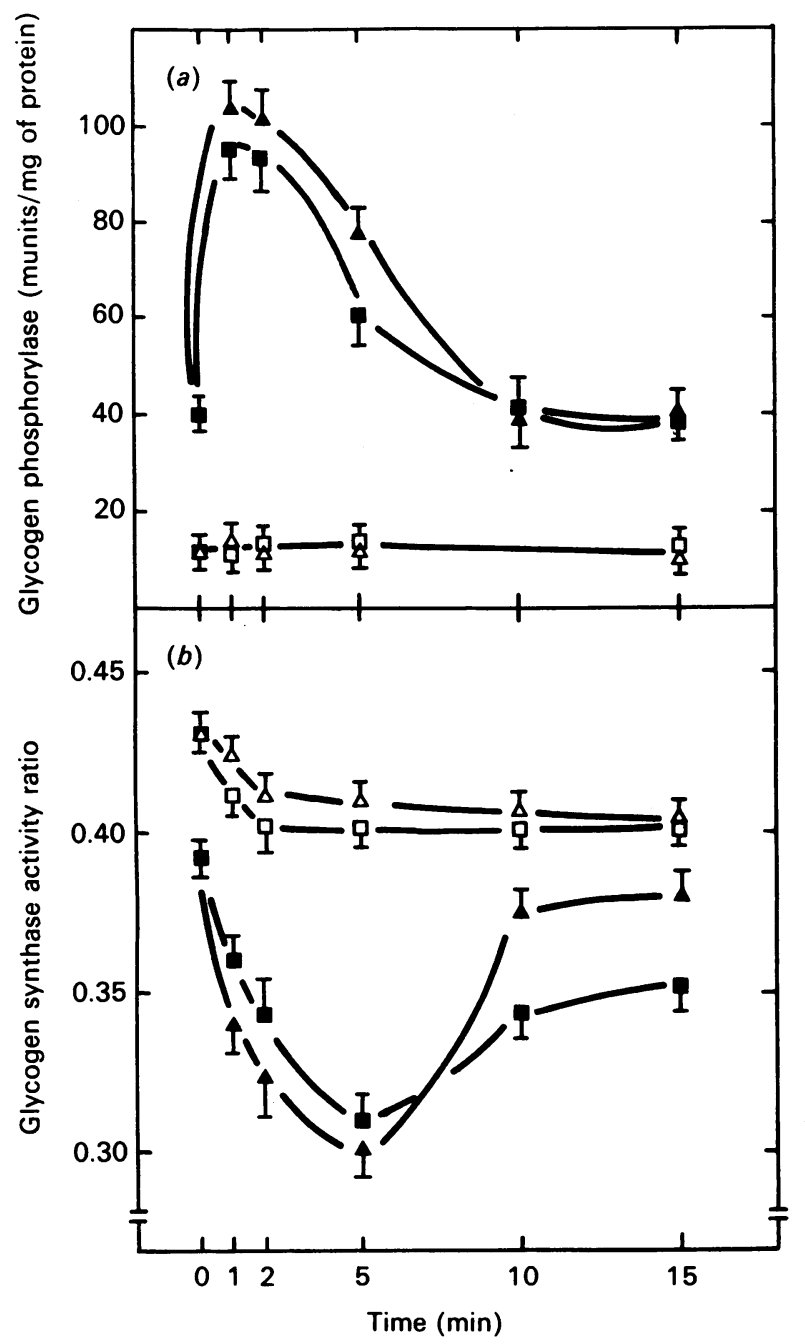

Fig. 1. Time-dependent effects of $\mathbf{P G E}_{2}$ and $\mathrm{PGF}_{2 \alpha}$ on glycogen synthase and glycogen phosphorylase activities

Hepatocytes incubated in normal $(\boldsymbol{\Lambda}, \mathbf{\square})$ or $\mathrm{Ca}^{2+}$-depleted medium $(\triangle, \square)$ were treated with $25 \mu \mathrm{M}-\mathrm{PGE}_{2}(\square, \square)$ or $20 \mu \mathrm{M}-\mathrm{PGF}_{2 \alpha}(\Delta, \Delta)$ for different times. Extracts were then prepared, and glycogen phosphorylase activity $(a)$ and glycogen synthase activity ratio $(b)$ were measured as indicated. Results are expressed as means \pm S.E.M. of at least four independent experiments. of glycogen synthase in a time-dependent manner (Fig. 1). The maximal activation of glycogen phosphorylase was achieved for both prostaglandins after 1-2 min of incubation, and the activity was increased more than 2fold over the control values. The maximal decrease in the glycogen synthase activity ratio was observed in both cases at $5 \mathrm{~min}$ (about $25 \%$ ).

In order to investigate the possible role of $\mathrm{Ca}^{2+}$ in the mechanism of action of prostaglandins, the cells were resuspended in a $\mathrm{Ca}^{2+}$-free medium which included $1 \mathrm{mM}$-EGTA. In the absence of $\mathrm{Ca}^{2+}$ neither $\mathrm{PGE}_{2}$ nor $\mathrm{PGF}_{2 \alpha}$ modified the activity of glycogen phosphorylase or altered the activity ratio of glycogen synthase (Fig. 1).

When hepatocytes were treated with different concentrations of $\mathrm{PGE}_{2}$ and $\mathrm{PGF}_{2 \alpha}$, a dose-dependent activation of glycogen phosphorylase was observed (Fig. 2a). The half-maximal effect was obtained with $1 \mu \mathrm{M}-\mathrm{PGE}_{2}$ or $-\mathrm{PGF}_{2 \alpha}$. The effect on glycogen synthase was also dependent on the concentration of prostaglandin used; $0.5 \mu \mathrm{M}-\mathrm{PGE}_{2}$ or $-\mathrm{PGF}_{2 \alpha}$ was already effective (Fig. $2 b$ ).

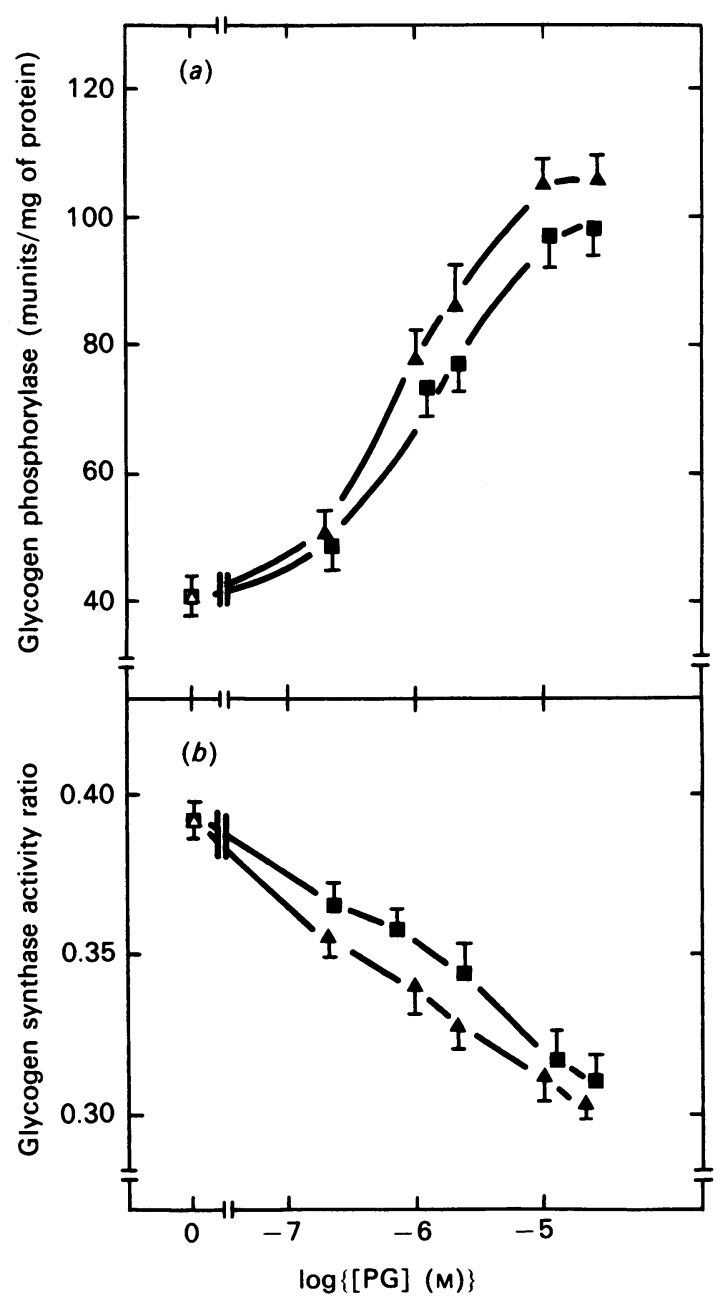

Fig. 2. Concentration-dependent effects of $P G E_{2}$ and $P G F_{2 \alpha}$ on glycogen synthase and glycogen phosphorylase activities

Cells were incubated with different concentrations of $\mathrm{PGE}_{2}$ (D) and $\mathrm{PGF}_{2 \alpha}(\Delta)$ for $5 \mathrm{~min}$. Then glycogen phosphorylase activity $(a)$ and glycogen synthase activity ratio $(b)$ were measured. Results are expressed as means \pm S.E.M. of at least four independent experiments. 


\section{Effects of $\mathrm{PGE}_{2}$ and $\mathrm{PGF}_{2 \alpha}$ on the phosphorylation state of glycogen synthase}

We next studied whether the inactivation of glycogen synthase by $\mathrm{PGE}_{2}$ or $\mathrm{PGF}_{2 \alpha}$ was the result of the phosphorylation of the enzyme. Isolated hepatocytes were preincubated with $\left[{ }^{32} \mathrm{P}\right] \mathrm{P}_{\mathrm{i}}$ and, after treatment with prostaglandins, glycogen synthase was immunoprecipitated, separated by polyacrylamide-gel electrophoresis and subjected to autoradiography. Treatment of the cells with $25 \mu \mathrm{M}-\mathrm{PGE}_{2}$ or $20 \mu \mathrm{M}-\mathrm{PGF}_{2 \alpha}$ for $5 \mathrm{~min}$

(a)

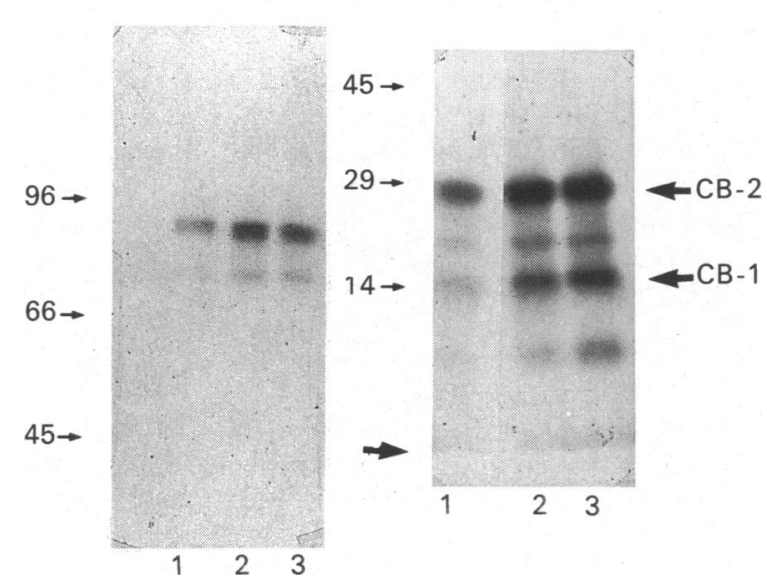

Fig. 3. Electrophoretic analysis of ${ }^{32} \mathbf{P}$-labelled glycogen synthase

${ }^{32} \mathrm{P}$-labelled glycogen synthase was immunoprecipitated from $\left[{ }^{32} \mathrm{P}\right] \mathrm{P}_{1}$-preincubated cells and subjected to polyacrylamide-gel electrophoresis before $(a)$ or after $(b) \mathrm{CNBr}$ treatment. Lane 1 is an autoradiogram of immunoprecipitated protein from control cells; lane 2, immunoprecipitated protein from cells exposed to $25 \mu \mathrm{M}-\mathrm{PGE}_{2}$ for $5 \mathrm{~min}$; lane 3 , immunoprecipitated protein from cells exposed to $20 \mu \mathrm{M}-\mathrm{PGF}_{2 \alpha}$ for $5 \mathrm{~min}$. Molecular masses (in $\mathrm{kDa}$ ) of standard proteins are shown on the left of the Figure. The bottom arrow shows the position of the front. increased by about 2 -fold the amount of ${ }^{32} \mathrm{P}$ bound to the $88 \mathrm{kDa}$ subunit of the enzyme (Fig. $3 a$, Table 1), suggesting that the inactivation by prostaglandins observed was related to the phosphorylation of glycogen synthase.

In order to determine the effects of both prostaglandins on the $\mathrm{CNBr}$ fragments of glycogen synthase, immunoprecipitated ${ }^{32} \mathrm{P}$-labelled glycogen synthase was subjected to $\mathrm{CNBr}$ cleavage and the resulting phosphopeptides were resolved by electrophoresis in 6-20\%-gradient polyacrylamide gels. Both $\mathrm{PGE}_{2}$ and $\mathrm{PGF}_{2 \alpha}$ increased the content of $\left[{ }^{32} \mathrm{P}\right] \mathrm{P}_{i}$ in two $\mathrm{CNBr}$ phosphopeptides, CB-1 and CB-2 (Fig. 3b). Radioactivity associated with CB-2 was increased by $\mathrm{PGE}_{2}$ or $\mathrm{PGF}_{2 \alpha}$ about 1.8 -fold, whereas radioactivity present in $\mathrm{CB}-1$ was increased 2.2-fold (Table 1) with respect to the control. These results demonstrate that prostaglandins stimulate the phosphorylation of hepatic glycogen synthase at multiple sites.

In agreement with the results presented above, when $\mathrm{Ca}^{2+}$ was omitted from the incubation medium and 1 mM-EGTA was included, no effects of either $\mathrm{PGE}_{2}$ or $\mathrm{PGF}_{2 \alpha}$ on the phosphorylation state of the glycogen synthase subunit or $\mathrm{CNBr}$ fragments were observed (Table 1).

\section{DISCUSSION}

We have shown that $\mathrm{PGE}_{2}$ and $\mathrm{PGF}_{2 \alpha}$ inactivated glycogen synthase and activated glycogen phosphorylase in rat hepatocytes. The time courses of the effects of prostaglandins on both enzymes were similar to those of the glycogenolytic hormones such as glucagon, adrenaline and vasopressin, or glycogenolytic agents such as vanadate [13,21-24]. Maximal inactivation of glycogen synthase occurred at about $5 \mathrm{~min}$, and activation of phosphorylase reached a peak at about 2 min, indicating a rapid response of the glycogenolytic process. The halfmaximal concentration of prostaglandins affecting both enzymes was $1 \mu \mathrm{M}$, in agreement with the concentrations of prostaglandins reported to stimulate glucose output in perfused rat livers and hepatocytes [3-7]. This concentration seems rather high for a biological effect. However,

\section{Table 1. Effects of $\mathrm{PGE}_{2}$ and $\mathrm{PGF}_{2 \alpha}$ on the phosphorylation state of glycogen synthase}

${ }^{32} \mathrm{P}$-labelled glycogen synthase from control or prostaglandin-treated cells, incubated in normal or $\mathrm{Ca}^{2+}$-depleted medium, was immunoprecipitated. Electrophoresis was performed before or after $\mathrm{CNBr}$ treatment. Autoradiograms of gels were scanned, and the peaks were integrated. Results are expressed as a percentage of the values of the peaks from control cells, and are means \pm S.E.M. of at least four experiments performed on different days.

\begin{tabular}{lcccc}
\hline & & \multicolumn{3}{c}{${ }^{32} \mathrm{P}-\mathrm{CNBr}$ fragments } \\
\cline { 3 - 5 } & $\begin{array}{c}\text { Glycogen synthase } \\
\text { 32P-labelled subunit }\end{array}$ & $\mathrm{CB}-2$ & $\mathrm{CB}-1$ & $\mathrm{CB}-2 / \mathrm{CB}-1$ \\
\hline $\mathrm{Ca}^{2+}$ & & & & \\
$\mathrm{Control}^{2}$ & 100 & 100 & 100 & $3.1 \pm 0.3$ \\
$\mathrm{PGE}_{2}$ & $188 \pm 12$ & $174 \pm 18$ & $224 \pm 15$ & $1.9 \pm 0.2$ \\
$\mathrm{PGF}_{2 \alpha}$ & $190 \pm 10$ & $180 \pm 15$ & $221 \pm 20$ & $1.8 \pm 0.2$ \\
$\mathrm{No} \mathrm{Ca}^{2+}$ & & & & \\
$\mathrm{Control}$ & 100 & 100 & 100 & \\
$\mathrm{PGE}_{2}$ & $105 \pm 7$ & $98 \pm 10$ & $105 \pm 9$ & \\
PGF $_{2 \alpha}$ & $103 \pm 5$ & $110 \pm 8$ & $102 \pm 12$ & \\
& & & &
\end{tabular}


hepatocytes are able to metabolize prostaglandins rapidly [25-27]. Also, it is possible that a high local intrahepatic concentration of prostaglandins exists, since it appears that prostaglandins secreted from non-parenchymal liver cells may influence parenchymal liver-cell metabolism [7].

The effects of $\mathrm{PGE}_{2}$ and $\mathrm{PGF}_{2 \alpha}$ on glycogen synthase and phosphorylase were dependent on the presence of $\mathrm{Ca}^{2+}$ in the incubation medium, suggesting that these effectors act in a manner similar to the $\mathrm{Ca}^{2+}$-dependent hormones. Several studies in perfused rat livers indicate that the actions of prostaglandins on glycogenolysis are closely correlated with $\mathrm{Ca}^{2+}$ concentrations $[3,4]$. Although it has been reported that prostaglandins stimulate phosphoinositide breakdown in different cell systems [28-30], no information is at present available to indicate that prostaglandins exert this effect in liver parenchymal cells. However, Altin \& Bygrave [4] suggested that the action of PGF $_{2 \alpha}$ in liver may involve phosphatidylinositol turnover. It could be considered that our finding that in the absence of $\mathrm{Ca}^{2+}$ no effects of prostaglandins are seen is inconsistent with the report that in perfused rat liver PGF $_{2 \alpha}$ stimulated glucose output and other responses in both $10 \mu \mathrm{M}$ - and $1.3 \mathrm{mM}^{-\mathrm{Ca}^{2+}}[4]$. However, under our conditions the calculated concentration of $\mathrm{Ca}^{2+}$ is about $30 \mathrm{nM}$ [31], whereas the lower concentration used in ref. [4] is $10 \mu \mathrm{M}$. This difference in free $\mathrm{Ca}^{2+}$ concentration is decisive in order to observe $\mathrm{Ca}^{2+}$-mediated effects in liver cells $[31,32]$.

We demonstrated that the inactivation of glycogen synthase by $\mathrm{PGE}_{2}$ and $\mathrm{PGF}_{2 \alpha}$ was correlated with an increase in the phosphorylation state of the subunit of the enzyme. The increase in $\left[{ }^{32} \mathrm{P}\right] \mathrm{P}_{1}$ content occurred in two $\mathrm{CNBr}$ fragments, $\mathrm{CB}-1$ and $\mathrm{CB}-2$, indicating that the enzyme was phosphorylated at multiple sites. Although more total phosphate was incorporated in CB-2, on a percentage basis the increase in the $\left[{ }^{32} \mathrm{P}\right] \mathrm{P}_{\mathrm{i}}$ content of $\mathrm{CB}$ 1 was more pronounced. This is similar to the pattern of phosphorylation observed after treatment of hepatocytes with glycogenolytic agents such as vasopressin, adrenaline and vanadate $[1,2,14]$. These data prove the covalent nature of the modification of glycogen synthase by prostaglandins. As with glycogen synthase and phosphorylase activities, this effect of $\mathrm{PGE}_{2}$ and $\mathrm{PGF}_{2 \alpha}$ required the presence of $\mathrm{Ca}^{2+}$ in the incubation medium. In the absence of $\mathrm{Ca}^{2+}$, the phosphorylation state of glycogen synthase subunit or $\mathrm{CNBr}$ fragments was unchanged by $\mathrm{PGE}_{2}$ or $\mathrm{PGF}_{2 \alpha}$. These results suggest that $\mathrm{Ca}^{2+}$-dependent glycogen synthase kinases are involved in the mechanism of action of prostaglandins.

Although $\mathrm{PGE}_{2}$ and $\mathrm{PGF}_{2 \alpha}$ appear to cause the breakdown of glycogen in hepatocytes via a similar mechanism to that of $\mathrm{Ca}^{2+}$-dependent hormones, the physiological meaning of this effect seems to be very different. Prostaglandins are thought to mediate the effects of different glycogenolytic agents. It has been proposed that effectors such as phorbol esters, arachidonic acid, platelet-activating factor or heat-aggregated IgG [5,8-11], activate glycogenolysis in liver parenchymal cells by stimulating the synthesis of prostaglandins such as $\mathrm{PGE}_{2}, \mathrm{PGF}_{2 \alpha}$ or $\mathrm{PGD}_{2}$ from non-parenchymal cells. The released prostaglandins would then be responsible for the activation of glycogenolysis in the parenchymal cells. Our results, indicating that $\mathrm{PGE}_{2}$ and $\mathrm{PGF}_{2 \alpha}$ are able to modify the activation state of glycogen synthase and phosphorylase, support the above proposal.
We thank Dr. R. W. Hanson and Dr. A. Wynshaw-Boris (Case Western Reserve University) for critical reading of the manuscript. We also thank Anna Vilalta for her valuable technical assistance. This work was supported by a grant from the Comisión Asesora a la Investigación Científica y Técnica (CAICYT PR83-2750). J. E. R.-G. was the recipient of a fellowship from the Formación de Personal Investigador (Ministry of Education, Spain).

\section{REFERENCES}

1. Ariño, J., Mor, A., Bosch, F., Baanante, I. V.\& Guinovart, J. J. (1984) FEBS Lett. 170, 310-314

2. Ciudad, C., Camici, M., Ahmad, Z., Wang, Y., DePaoliRoach, A. A. \& Roach, P. J. (1984) Eur. J. Biochem. 142, $511-520$

3. Buxton, D. B., Fisher, R. A., Briseno, D. L., Hanahan, D. J. \& Olson, M. S. (1987) Biochem. J. 243, 493-498

4. Altin, J. G. \& Bygrave, F. L. (1988) Biochem. J. 249, 677-685

5. Casteleijn, E., Kuiper, J., Van Rooij, H. C. J., Kamps, J. A. A. M., Koster, J. F. \& Van Berkel, T. J. C. (1988) Biochem. J. 250, 77-80

6. Casteleijn, E., Kuiper, J., Van Rooij, H. C. J., Kamps, J. A. A. M., Koster, J. F. \& van Berkel, T. C. J. (1988) J. Biol. Chem. 263, 2699-2703

7. Casteleijn, E., Kuiper, J., Van Rooij, H. C. J., Koster, J. F. \& Van Berkel, T. J. C. (1988) Biochem. J. 252, 601-605

8. Altin, J. G., Dieter, P. \& Bygrave, F. L. (1987) Biochem. J. $245,145-150$

9. Garcia-Sainz, J. A. \& Hernandez-Sotomayor, S. M.-T. (1985) Biochem. Biophys. Res. Commun. 132, 204 209

10. Mendlovic, F., Corvera, S. \& Garcia-Sainz, J. A. (1984) Biochem. Biophys. Res. Commun. 123, 507-514

11. Birmelin, M. \& Decker, K. (1984) Eur. J. Biochem. 142, 219-225

12. Dieter, P., Shulze-Specking, A. \& Decker, K. (1986) Eur. J. Biochem. 159, 451-457

13. Massague, J. \& Guinovart, J. J. (1977) FEBS Lett. 82, 317-320

14. Bosch, F., Ariño, J., Gomez-Foix, A. M. \& Guinovart, J. J. (1987) J. Biol. Chem. 262, 218-222

15. Ariño, J. \& Guinovart, J. J. (1986) Biochem. Biophys. Res. Commun. 134, 113-119

16. Laemmli, U. K. (1970) Nature (London) 227, 680-685

17. Guinovart, J. J., Salavert, A., Massague, J., Ciudad, C. J., Salsas, E. \& Itarte, E. (1979) FEBS Lett. 106, 284-288

18. Van der Werve, G., Hue, L. \& Hers, H.-G. (1977) Biochem. J. 162, 135-142

19. Gornall, A. G., Bardawill, C. J. \& David, M. M. (1949) J. Biol. Chem. 177, 751-756

20. Layne, E. (1957) Methods Enzymol. 3, 450-451

21. Hutsen, N. J., Brumley, F. T., Assimacopoulos, F. D., Harper, S. C. \& Exton, J. H. (1976) J. Biol. Chem. 251, 5200-5208

22. Hems, D. A., Rodrigues, L. M. \& Whitton, P. D. (1978) Biochem. J. 172, 311-317

23. Strickland, W. G., Blackmore, P. F. \& Exton, J. H. (1980) Diabetes 29, 617-622

24. Massague, J. \& Guinovart, J. J. (1978) Biochim. Biophys. Acta 543, 269-272

25. Dawson, W., Jessup, S. J., McDonald-Gibson, W., Ramsell, P. \& Shaw, J. E. (1970) Br. J. Pharmacol. 39, 585598

26. Garrity, M. J., Brass, E. P. \& Robertson, R. P. (1983) Clin. Res. 32, 47 
27. Okumura, T., Nakayama, R., Sago, T. \& Saito, K. (1985) Biochim. Biophys. Acta 838, 197-207

28. Macphee, C. H., Drummond, A. H., Otto, A. M. \& DeAsua, L. J. (1984) J. Cell. Physiol. 119, 35-40

29. Mene, P., Dubyak, G. R., Scarpa, A. \& Dunn, M. J. (1987) Biochem. Biophys. Res. Commun. 142, 579-586

Received 13 October 1988/27 February 1989; accepted 1 March 1989
30. Davis, J. S., Weakland, L. L., Weilland, D. A., Farese, R. V. \& West, L. A. (1987) Proc. Natl. Acad. Sci. U.S.A. 84, 3728-3732

31. Blackmore, P. F., Strickland, G. W., Bocckino, S. B. \& Exton, J. H. (1986) Biochem. J. 237, 235-242

32. Renard, D., Poggioli, J., Berthon, B. \& Claret, M. (1987) Biochem. J. 243, 391-398 